\title{
The Difference of Albumin, Tryptophan Amino Acid and IL-17 in Several Stages of Leprosy
}

\author{
Mohammad Zen Rahfiludin ${ }^{1}$, Siti Fatimah ${ }^{2}$ \\ Departement of Public Health Nutrition \\ Faculty of Public Health, Diponegoro University \\ Semarang, Indonesia \\ Adriyan Pramono ${ }^{3}$, Diana Nur Afifah ${ }^{4}$ \\ Department of Nutrition Science CENURE \\ Faculty of Medicine, Diponegoro University \\ Semarang, Indonesia
}

\author{
Onny Setiani ${ }^{5}$ \\ Departement of Environmental Health \\ Faculty of Public Health, Diponegoro University \\ Semarang, Indonesia \\ Diana Nurhayati Affandi ${ }^{6}$ \\ Department of Biochemistry, \\ Faculty of Medicine, Diponegoro University, \\ Semarang, Indonesia
}

\begin{abstract}
Nutrition linked to multiple components, systems, and processes, including those occurring during diseases, such as infection. Leprosy can be regarded as the most infectious, transmittable and long lasting disease among all infectious diseases. There have been many researches that examine nutrition with infectious disease but only a few research examined nutritional status and leprosy. The purpose of this research was to find out the difference of protein status and IL17 in several stages of leprosy. This was a cross sectional study and was conducted on people who live in the same house or near the leprosy patients in Brebes District, Central Java, Indonesia. There are 90 people contacts households who were eligible to be screened with the examination of IgM anti PGL-1 using ELISA. Of the 90 people who were examined, 10 of them were classified as seropositive leprosy, while the 80 others were classified as seronegative leprosy, from the 80 people who were classified as seronegative leprosy, 10 were randomly picked. Ten people who were classified as leprosy type MB also included. Mean albumin serum and tryptophan amino acid tend to decrease in several stages of leprosy, but there was no significant difference ( $p=$ 0,401 and $p=0,318$ ). IL-17 level was highest at seropositive group and lowest at seronegative group, although there was no significant difference $(p=0,217)$. It can be concluded that although there were no correlation statistically, but albumin serum, tryptophan amino acid tend to decrease and IL-17 level was fluctuate according to the severity of leprosy.
\end{abstract}

Keywords-Leprosy; Albumin; Tryptophan Amino Acid; Interleukin-17

\section{INTRODUCTION}

Nutrition is a fundamental aspect of life, and it is linked to multiple components, systems, and processes, including those occurring during diseases, such as infection. In this context, nutrition has a close relationship with infection. For example, malnutrition is considered to be an important cause of immunodeficiency worldwide, predisposing the malnourished to multiple infections. All forms of immunodeficiency predispose to malnutrition, particularly those opportunistic, related to those altered states of immunity. Malnutrition is a condition that, by itself, increases the host's susceptibility to infectious diseases, and these infections, in turn, have negative repercussions on the metabolism of the host, worsening the nutritional state [1].

Leprosy can be regarded as the most infectious, transmittable and long lasting disease among all infectious diseases. It is a chronic and granulomatous disease, mainly caused by two bacteria named Mycobacterium leprae and Mycobacterium lepromatosis [2]. Leprosy is classified into paucibacillary (PB) and multibacillary (MB) leprosy based on the number of skin lesions [3]. In addition to the symptoms and signs due to the infection itself, patients with leprosy can experience episodic immunologically mediated acute inflammatory responses, called reactions [4]. After infection the response of host immune system determines the course of the disease [5]. The protection against infections is mediated by natural boundaries and by their immune response. The natural boundaries can be mechanical, chemical or biological. The immune response is activated when the pathogen overcomes these natural boundaries. Nutritional deficiency can affect both natural boundaries and lead to suppressed immune response [6].

One of the nutrition that plays role is protein. Determination of protein status can be measured by tryptophan amino acid and albumin serum. Tryptophan amino acid was an essential amino acid and has to be present in daily food intake. Interleukin-17 (IL-17A) is a cytokine secreted exclusively by activated T-cells. The IL-17 signaling system is operative in disparate tissues such as articular cartilage, bone, meniscus, brain, hematopoietic tissue, kidney, lung, skin and intestine. Thus, the evolving IL-17 family of ligands and receptors may play an important role in the homeostasis of tissues in the immune system of leprosy cases [7].

Leprosy incidents in Central Java were increasing from 1.801 cases in 2015 to 1.864 cases in 2016 . There were 8 districts with the highest prevalence of leprosy and classified as the high burden districts $(22,86 \%)$. One of the districts in Central Java with the highest prevalence of leprosy was Brebes [8].

There have been many researches which examined nutrition with infectious disease [9]-[11]. However, only a few 
research examined nutritional status and leprosy. In addition leprosy is a disease related to immunity that is affected by protein status and amino acid. The purpose of this research was to find out the difference of albumin, tryptophan amino acid and IL-17 in several stages of leprosy in Brebes District, Central Java, Indonesia.

\section{METHODS}

This was a cross sectional study and was conducted on people who live in the same house or near the leprosy patients in Brebes District, Central Java, Indonesia. The inclusion criteria of this study were individuals who live in the same house or near leprosy subjects with aged 25-50 years (male or female). In addition, those who were not showed any anamnestic and clinical symptoms of leprosy and tuberculosis, not taking any anti-leprosy, anti-tuberculosis and antiimmunosuppressant medication in the last three months before blood tests, not suffer from illnesses (diabetes mellitus, HIV, thalassemia), has BMI above $18 \mathrm{~kg} / \mathrm{m}^{2}$ and willing to participate in the study by approving to sign the informed consent. There were 90 contacts households who were eligible to be screened with the examination of IgM anti PGL-1 using ELISA (polyclonal rabbit anti-human IgM / HRP, Dako®). Of the 90 people who were examined, 10 of them were classified as seropositive leprosy (IgM anti PGL-1 > $600 \mathrm{mg} / \mathrm{dl}$ ) while the 80 others were classified as seronegative leprosy (IgM anti PGL-1 $<600 \mathrm{mg} / \mathrm{dl}$ ), from the 80 people who were classified as seronegative leprosy, 10 were randomly picked using systematic random sampling by forming a sampling framework from number 1-80. Ten people who were classified as leprosy type MB also included.

Examination of IgM anti PGL-1 performed at the Tropical Disease Diagnostic Centre (TDDC) Airlangga University, Surabaya, Indonesia. Albumin serum level tests was examined using Albumin BCG in Abbott Laboratories. Tryptophan amino acid was examined using ELISA (DRG Instrument GmbH, Germany, Cat: EIA 5505) and were conducted at Prodia laboratory. IL-17 level was measured by High Sensitivity ELISA BMS2017HS diagnostic test kits using Microplate Reader ELx800 GAKI biotech laboratory instrument. Ethical clearance with No: 193/EC/FKM/2015 was obtained from the Commission of Ethics of Medical and Public Health Research, Faculty of Public Health, Diponegoro University.

\section{RESULT}

The mean age of subjects in several stages of leprosy from seronegative, seropositive to leprosy type MB were 40,5 $\pm 4,7,36,6 \pm 6,7$ and $37,3 \pm 4,8$ years old, respectively. No differences in age, BMI, energy intake and intake of protein (p>0.05) (Table 1).

Mean albumin serum and tryptophan amino acid were highest at seronegative group and lowest at leprosy type $\mathrm{MB}$ group but there were no significant difference $(\mathrm{p}=0,401$ and $\mathrm{p}=0,318$ ). IL-17 level was highest at seropositive group and lowest at seronegative group, although there was no significant difference $(\mathrm{p}=0,217)$ (Table 2). Results of albumin serum, tryptophan amino acid and IL-17 in several stages of leprosy

TABLE I. CHARACTERISTICS OF SUBJECTS IN SEVERAL STAGES OF LEPROSY

\begin{tabular}{|l|l|l|l|}
\hline Variable & \multicolumn{1}{|c|}{$\begin{array}{c}\text { Seronegative } \\
(\mathbf{n = 1 0})\end{array}$} & $\begin{array}{c}\text { Seropositive } \\
(\mathbf{n}=\mathbf{1 0})\end{array}$ & \multicolumn{1}{|c|}{$\begin{array}{c}\text { Leprosy type } \\
\mathbf{M B}(\mathbf{n}=\mathbf{1 0})\end{array}$} \\
\hline $\begin{array}{l}\text { Age } \\
(\text { years })\end{array}$ & $40,5 \pm 4,7$ & $36,6 \pm 6,7$ & $37,3 \pm 4,8$ \\
\hline $\begin{array}{l}\text { BMI } \\
\left(\mathrm{kg} / \mathrm{m}^{2}\right)\end{array}$ & $22,9 \pm 1,5$ & $22,7 \pm 2.1$ & $22,2 \pm 1,8$ \\
\hline $\begin{array}{l}\text { Energy } \\
(\text { calorie })\end{array}$ & $1883 \pm 550$ & $1710 \pm 706$ & $1349 \pm 345$ \\
\hline Protein $(\mathrm{g})$ & $72,7 \pm 46,2$ & $61,2 \pm 32,0$ & $57,1 \pm 33,7$ \\
\hline
\end{tabular}

TABLE II. RESULTS OF ALBUMIN SERUM, TRYPTOPHAN AMINO ACID AND IL-17 IN SEVERAL STAGES OF LEPROSY

\begin{tabular}{|c|c|c|c|c|}
\hline Group & n & $\begin{array}{c}\text { Albumin } \\
\text { Serum } \\
(\mathrm{g} / \mathrm{dl})\end{array}$ & $\begin{array}{c}\text { Tryptophan } \\
\text { Amino Acid } \\
(\mu \mathrm{g} / \mathrm{ml})\end{array}$ & $\begin{array}{c}\text { IL-17 } \\
(\mathrm{pg} / \mathrm{ml})\end{array}$ \\
\hline $\begin{array}{l}\text { Seronegative } \\
\text { leprosy (IgM } \\
\text { anti PGL-1 } \\
<600 \mathrm{mg} / \mathrm{dl})\end{array}$ & 10 & $4.48 \pm 0.319^{\mathrm{a}}$ & $\begin{array}{l}11.95 \pm \\
4.207^{\mathrm{a}}\end{array}$ & $\begin{array}{l}0.319 \pm \\
0.3791^{\mathrm{a}}\end{array}$ \\
\hline $\begin{array}{l}\text { Seropositive } \\
\text { leprosy(IgM } \\
\text { anti PGL-1 } \\
>600 \mathrm{mg} / \mathrm{dl})\end{array}$ & 10 & $4.33 \pm 0.365^{\mathrm{a}}$ & $\begin{array}{l}10.86 \pm \\
5.176^{\mathrm{a}}\end{array}$ & $\begin{array}{l}0.621 \pm \\
1.7611^{b}\end{array}$ \\
\hline $\begin{array}{l}\text { Leprosy type } \\
\text { MB }\end{array}$ & 10 & $4.24 \pm 0.481^{\mathrm{a}}$ & $8.74 \pm 4.724^{\mathrm{a}}$ & $\begin{array}{l}0.605 \pm \\
4.4715^{\mathrm{b}}\end{array}$ \\
\hline $\mathrm{P}$ & & $0.401^{\mathrm{c}}$ & $0.318^{\mathrm{c}}$ & $0.217^{\mathrm{d}}$ \\
\hline
\end{tabular}

\section{DISCUSSION}

Albumin serum in this study was range from $4.24-4.48$ $\mathrm{g} / \mathrm{dl}$ in several stages of leprosy and were categorized as normal. This result shows a higher albumin serum level compare to other study that discuss about albumin serum in tuberculosis and HIV patients [12]. This research shows that albumin serum level is decreasing in several stages of leprosy. This result is in line with other study that stated the reduction of serum albumin is correlated with the poorer condition of the patients [13]. It is also stated that lower serum albumin levels correlate with an increased risk of morbidity [14]. Serum albumin concentration is a strong independent predictor of mortality, pulmonary tuberculosis, severe anemia, wasting, and weight loss among HIV-infected individuals [15].

Tryptophan amino acid in seronegative leprosy was slightly lower than other study conducted in Poland [16]. Tryptophan amino acid is an essential amino acid which important not only for the host but also bacteria. Indoleamine 2, 3-dioxygenase (IDO) is an enzyme that breaks tryptophan amino acid into tryptophan metabolites such as kynurenine [17]. However, the tryptophan metabolites might also function as either suppressors of specific $\mathrm{T}$ cell clones or inducers of $\mathrm{T}$ regulatory cells and IL-10 secretion, leading to the subsequent 
loss of responsiveness [18]. IDO could be considered to be a double-edged sword in the immune response against pathogens. Since many microbial organisms rely on the essential tryptophan amino acid, its degradation by IDOexpressing cells of the innate immune system was favored as the major IDO-mediated mechanism against infections [19]. Thus, bacteria will not able to use it so the development of bacteria will be disturbed, and if this process continues tryptophan amino acid in host will reduce. The reduction of tryptophan amino acid, will decrease $\mathrm{T}$ cell poliferation and will have an impact on $\mathrm{T}$ cell depletion. On the one hand, IDO directly suppresses the replication of certain parasites and bacteria [20], or at least prevents viral spread [21,22], on the other hand, it also acts on host cells to suppress immune reactions thereby promoting infectious diseases [23].

IL-17 level in this research was highest at seropositive group and lowest at seronegative group. IL-17 level was affected by many factors one of them was the development of Th17 cell that inhibited in recognition process from $\mathrm{T}$ cell to APC cell. Mycobacterium leprae can interfere with host immune response by lowering costimulatory molecules activity of host cell. The expression of B7-1 and CD 28 were significantly decreased in patients with untreated lepromatous leprosy disease. Down regulation of B7-1 and CD 28 in lepromatous leprosy may be responsible for a defective $\mathrm{T}$ cell signaling by the B7-1/ CD 28 pathway due to M. leprae antigens [24]. Therefore, if this process ocurred, the development stages of Th17 cell will decrease and IL-17 will be disturbed.

In a study of patients with experimental wounds, individuals with either low serum protein or serum albumin were found to have significantly weaker wound healing than those with normal protein values [25]. In the contrary, the leprosy type MB group of this research has albumin serum of $4.24 \mathrm{~g} / \mathrm{dl}$ and classified as normal because the group consisted of patients who have taken medication.

In conclusion, there were no correlation since patients in leprosy type MB group had received treatment thus they have been recovering and during the treatment process protein depletion was decreasing. However albumin serum and tryptophan amino acid tend to decrease and IL-17 level was fluctuate according to the severity of leprosy.

\section{CONCLUSION}

It can be concluded that there were no significant difference of albumin serum, tryptophan amino acid and IL-17 in three stages of leprosy.

\section{ACKNOWLEDGMENT}

The authors are thankful to the Directorate of Research and Community Services and the Ministry of Research, Technology and Higher Education, as well as the Reseach Institute of Diponegoro University, which facilitated and funded this research.

\section{REFERENCES}

[1] Morales A, Mejia A, Olave C. Nutrition and Infection. Elsevier. 2016.

[2] Earla P. Long Lasting Disease: Leprosy. 2015;3(2):3-6. doi:10.4172/2332-0877.R1-001.

[3] WHO. WHO Expert Committee on Leprosy. Geneva; 2012.

[4] Public Health Quarterly Report. Leprosy: a rare , serious and curable mycobacterial disease Request to Report Cases of Suspected Foodrelated allergic reactions including Anaphylaxis. 2007;9934.

[5] Mohanty KK, Joshi B, Katoch K, Sengupta U. Leprosy Reactions : Humoral and Cellular Immune Responses to M . leprae , 65kDa , 28kDa , and. 2004;72(2):149-158.

[6] Maria C, Vázquez P, Simões R, et al. Micronutrients influencing the immune response in leprosy. 2014;29(1):26-36. doi:10.3305/nh.2014.29.1.6988.

[7] Moseley T., Haudenschild D., Rose L. Interleukin-17 Family and IL-17 receptors. Cytokine Growth Factor Rev. 2003;14.

[8] Central Java Provincial Health Office. Health Profile of Central Java Province in 2016. Semarang. 2016

[9] Fawzi W, Msamanga G. Micronutrients and adverse pregnancy outcomes in the context of HIV infection. Nutr Rev, 2004, vol. 62

[10] Meydani SN, Barnett S, Dallal JB, et al. Serum zinc and pneumonia in nursing home elderly. Am J Clin Nutr, 2007,vol. 86

[11] Cuevas LE, Koynagi A. Zinc and infection: a review, Ann Trop Paediatr, 2005, vol. 25

[12] Shingdang J, Bot Y, Ojo O, et al. Mycobacterial Diseases Serum Albumin / Globulin ratio in Tuberculosis and HIV Patients any Relationship ? 2016;6(1):1-6. doi:10.4172/2161-1068.1000199.

[13] Maclean S, Stietenroth K, Prange H, Pai V V, Ganapati R. Serum Markers of Treatment Success in Leprosy 1. 67(I):19-23.

[14] Nelms J. ALBUMIN AND INFLAMMATION. New England; 2015.

[15] Sudfeld CR, Isanaka S, Aboud S, et al. Association of Serum Albumin Concentration With Mortality, Morbidity, CD4 T-cell Reconstitution Among Tanzanians Initiating Antiretroviral Therapy. 2013;207. doi:10.1093/infdis/jit027.

[16] Comai S, Bertazzo A, Carretti N, Luisi S, Costa CVL. Serum Levels of Tryptophan , 5-Hydroxytryptophan and Serotonin in Patients Affected with Different Forms of Amenorrhea. :69-75.

[17] Schmidt S V, Schultze JL. New insights into IDO biology in bacterial and viral infections. 2014;5(August):1-12. doi:10.3389/fimmu.2014.00384.

[18] Amadeu TP, Fulco TDO. The role of indoleamine 2, 3 -dioxygenase in lepromatous leprosy immunosuppression. 2011:251-263. doi:10.1111/j.1365-2249.2011.04412.x.

[19] Werener E, Bitterlich G, FUchs D, Hausen A. Human macrophages degrade tryptophan upon induction by interferon-gamma. Life Sci. $1987 ; 41$.

[20] Schmitz J, Carlin J, Borden E. Beta interferon inhibits Toxo- plasma gondii growth in human monocyte-derived macrophages. Infect Immun. $1989 ; 57$.

[21] Terajima M, Leporati A. Role of indoleamine 2,3-dioxygenase in antiviral activity of interferon-gamma against vaccinia virus. Viral Immunol. 2005;18(722).

[22] Adams O, Besken K, CR M. Inhibition of human herpes simplex virus type 2 by interferon gamma and tumor necrosis factor alpha is mediated by indoleamine 2,3-dioxygenase. Microbes Infect. 2004;6(806).

[23] Loughman J, Hunstad D. Induction of indoleamine 2,3-dioxygenase by uropathogenic bacteria attenuates innate responses to epithelial infection. J Infect DisDis. 2012;205(1830).

[24] Agrewala J, Kumar B, Vohra H. Potential Role of B7-1 and CD28 molecules in immunosuppression in Leprosy. Clin Exp Immunol. 1998;111:56-63.

[25] Lindstedt E, Sandblom P: Wound healing in man: tensile strength of healing wounds in some patient groups. Ann Surg. 1975;181:842-846. 